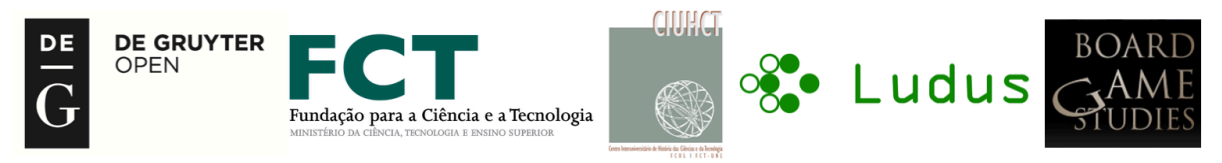

\title{
Stranger Games: The Life And times of THE spintriae
}

\author{
Eddie Duggan* \\ University of Suffolk
}

\begin{abstract}
In 2010 a Roman token was discovered in the mud of the Thames near Putney Bridge in London. When the token was discovered to have an erotic image on one side and a Roman numeral on the other, and was identified in a Museum of London press release as a rare Roman "brothel token", the press reported on the story in the expected manner, for example: "A Roman coin that was probably used by soldiers to pay for sex in brothels has been discovered on the banks of the River Thames" (Daily Telegraph, 4 Jan 2012) and "Bronze discs depicting sex acts, like the one discovered in London, were used to hire prostitutes - and directly led to the birth of pornography during the Renaissance" (The Guardian, 4 Jan 2012). Even before this particular spate of media interest, these curious tokens have generated confusion, speculation and prurience - often simultaneously. They are of interest to games scholars because the speculation often includes the suggestion these objects may have had a ludic function, and were used as game counters. This paper will look at some of the proposals that have been offered by way of explanation of these peculiar objects.
\end{abstract}

In 2010 a Roman token was discovered in the mud of the Thames near Putney Bridge in London. When the token was found to have an erotic image on one side and a Roman numeral on the other, and was identified in

${ }^{*}$ The author wishes to acknowledge the kind assistance of Eric Matthews in helping with the translation of some of the secondary source material from Italian into English, and also for his invaluable support in procuring secondary source material. The title of this paper, "Stranger Games", makes a punning reference to a previous paper by the author entitled "Strange Games", which was initially presented to the XVII Annual Board Game Studies Colloquium at UCS Ipswich, May 2014 and subsequently published in the Board Game Studies Journal as Duggan, E. (2015) "Strange Games: Some Iron Age examples of a four-player board game?" Board Game Studies Journal 9 pp. 17-40. A presentation based on an earlier draft of the present paper, entitled "Stranger Games", was included in the program of the XIX Annual Board Games Studies Colloquium hosted at the German Games Archive, Nuremburg, April 2016.

Board Game Studies Journal 11, pp. 101-121 DOI $10.1515 /$ bgs-2017-0005 
a Museum of London press release as a rare Roman "brothel token" (Figure 1 ), the British press reported on the story in the expected manner. For example: "A Roman coin that was probably used by soldiers to pay for sex in brothels has been discovered on the banks of the River Thames" (Figure 2) and "Bronze discs depicting sex acts, like the one discovered in London, were used to hire prostitutes - and directly led to the birth of pornography during the Renaissance" (Figure 3).

\title{
Roman brothel token discovered on Thames foreshore
}

\author{
5 January 2012 \\ The first known Roman brothel token to have \\ been discovered in London and most likely \\ Britain, is on temporary display at the Museum \\ of London.
}

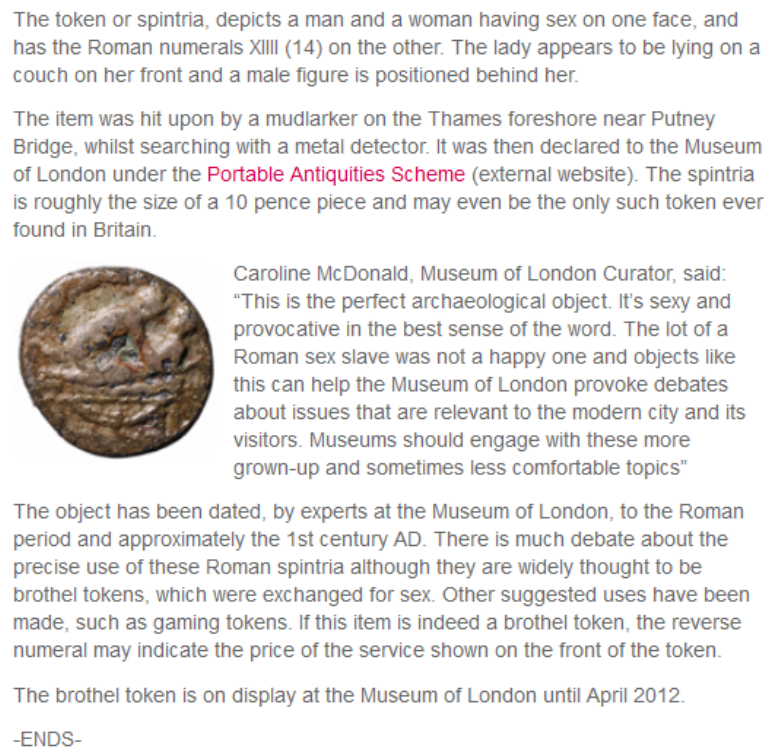

Caroline McDonald, Museum of London Curator, said "This is the perfect archaeological object. It's sexy and provocative in the best sense of the word. The lot of a Roman sex slave was not a happy one and objects like this can help the Museum of London provoke debates about issues that are relevant to the modern city and its visitors. Museums should engage with these more grown-up and sometimes less comfortable topics"

The object has been dated, by experts at the Museum of London, to the Roman period and approximately the 1 st century $A D$. There is much debate about the precise use of these Roman spintria although they are widely thought to be brothel tokens, which were exchanged for sex. Other suggested uses have been made, such as gaming tokens. If this item is indeed a brothel token, the reverse numeral may indicate the price of the service shown on the front of the token.

The brothel token is on display at the Museum of London until April 2012. -ENDS-

Figure 1: Museum of London, "Brothel Token" Press Release, January 5, 2012. Source: http://bit.1y/2x9juvq 


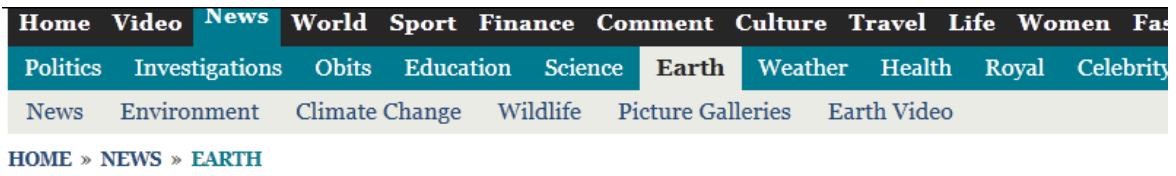

\section{Roman brothel token discovered in Thames}

A Roman coin that was probably used by soldiers to pay for sex in brothels has been discovered on the banks of the River Thames.

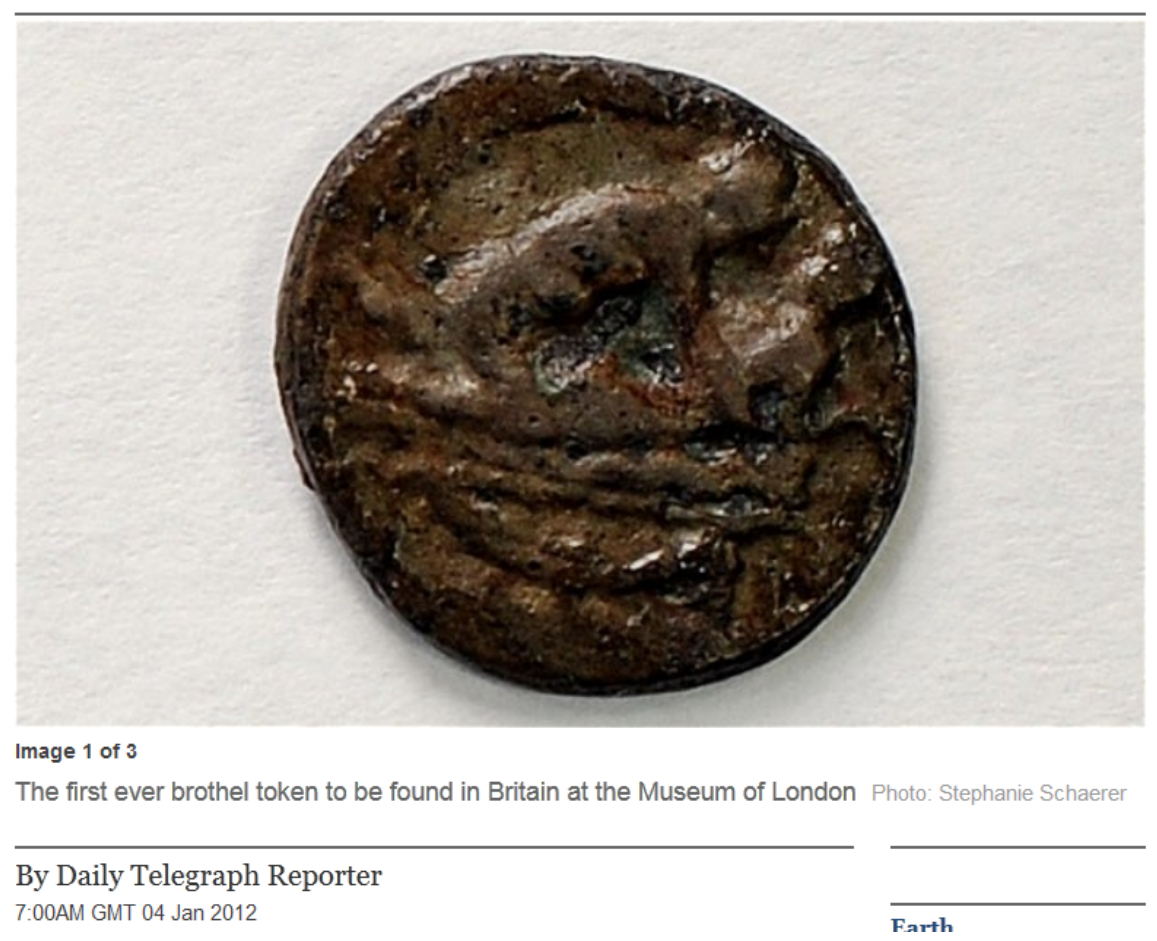

Figure 2: Daily Telegraph, "A Roman coin that was probably used by soldiers to pay for sex in brothels has been discovered on the banks of the River Thames", January 4, 2012. Source: http://www.telegraph.co.uk/news/earth/8991212/ Roman-brothel-token-discovered-in-Thames.html

Even before this particular spate of media interest, these curious tokens have generated confusion, speculation and prurience - often simultaneously. However, spintria may be of interest to games scholars because the conjecture over their use often includes suggestions that these objects may have had a ludic function, and were used as game counters. This paper will look at some of the proposals that have been offered by, inter alia, numismatists, economists, art historians and archaeologists, by way of explanation of these peculiar objects. 


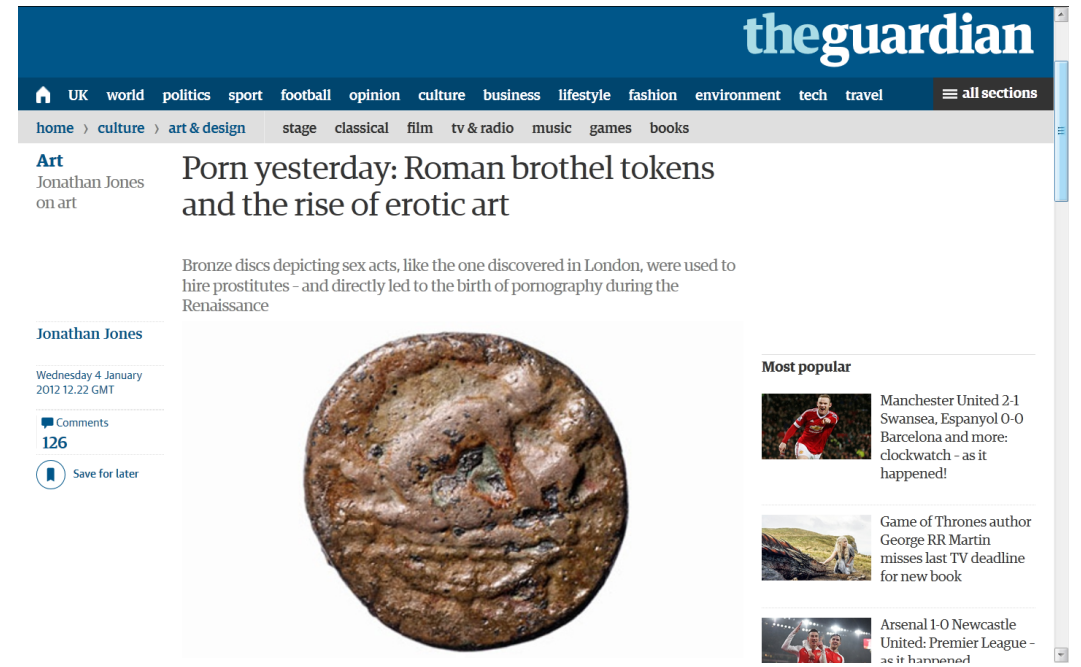

Figure 3: Jonathan Jones, "Bronze discs depicting sex acts, like the one discovered in London, were used to hire prostitutes - and directly led to the birth of pornography during the Renaissance" blog post, The Guardian, January 42012.

Source: http://www.theguardian.com/artanddesign/jonathanjonesblog/ 2012/jan/04/porn-roman-brothel-tokens-erotic-art

One of the most significant contemporary engagements with the spintria is an article by Ted Buttrey in The Numismatic Chronicle. While Buttrey describes the spintriae as objects that "defy explanation" (Buttrey 1973, p. 53), he identifies two distinct sets of spintriae: the first, of which more examples are known, are made of brass and measure 20-23 $\mathrm{mm}$ in diameter (Figure 4). The second, of copper, are smaller, 16-19 mm, and the Roman numeral on the reverse is prefixed with either the letter " $\mathrm{A}$ " or lambda " $\Lambda$ " (Figure 5). Both sets are characterized by an erotic scene of a couple engaged in heterosexual copulation or fellation on the obverse while the reverse depicts a Roman numeral, in the range I-XVI, within a circle surrounded by a wreath.

Buttrey notes that only two examples of the latter group, with the "A" or " $\Lambda$ " prefix, are in the British Museum while the former set is represented with twenty-one examples. A Portable Antiquities Scheme blog post by Kathryn Creed of the Museum of London corroborates Buttrey's enumeration as she notes the British Museum "has a collection of around 25 spintriae" (Creed 2012). 


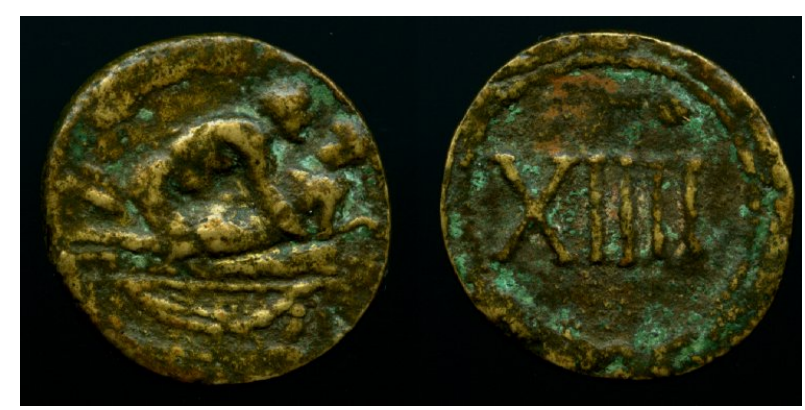

Figure 4: Spintria. Buttrey "Type 5". BM R.4476. C1st AD. Copper alloy. Diameter: $19 \mathrm{~mm}$. Image $\odot$ Trustees of the British Museum
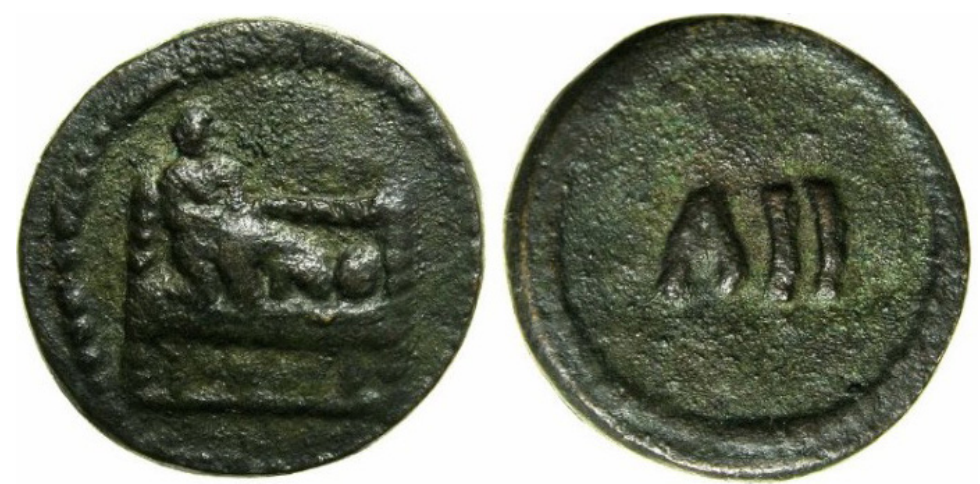

Figure 5: Spintria. Type 9, Series 2. C16-C 17 copy. Source: Pavlos S. Pavlou, Numismatist [online]. 1 .

https://www.vcoins.com/en/stores/pavlos_s_pavlou_numismatist/131/

product/roman16th_to_17th_cent_ad_copy_of_aespintriaeerotic_

sceneretrograde_roman_numerals_vii/222124/Default.aspx

\footnotetext{
${ }^{1}$ The reverse numeral in Figure 5, a C16-17th copy of a spintria, is identified as a "Reverse: IIV (retrograde VII)" by the auction site on which the item appears. However, if the tessera is rotated as in Figure 5, "IIV" can be seen as "AII". Buttrey (1973) refers to two series of spintria in the British Museum collection; the second series is characterized by the reverse numeral being prefixed with the letter "A". Buttrey identifies two examples of the second series in the British Museum collection; one of the two BM examples (AE22 4.15) has the same obverse/ reverse pairing as this Renaissance copy: it is labelled "Type 9, Series 2". The other example (AE19 4.23), labelled "Type 10, series 2", appears to be prefixed with a lambda rather than an A, i.e.: " $\Lambda I I I "$ (these examples are also identified by a handwritten note on a disc of paper in the coin tray). Both are contained in Tray 23 (spintriae) and may be seen by appointment with the Coins and Medals Department. A third example in the same tray in the BM collection (AE23 9.08), apparently overlooked by Buttrey, shows two figures treading grapes on the obverse and A XVI on the reverse. Unfortunately, photography is not permitted in the Coins and Medals study room so this example, un-recorded by Buttrey, cannot be shown here. However, the same die-pairing has been offered for auction. See Appendix A.
} 
However, a search of the British Museum's online collection yields only 11 results, which means that the intrepid spintriae inspector must visit the museum in person, having arranged in advance for the tokens to be brought out of storage. It is also worth pointing out that, while Buttrey draws a distinction between copper and brass, the British Museum does not, because "bronze and brass have been used interchangeably in the old documentation" while "copper alloy is the broad term for both" and is the preferred term in records relating to Roman coins. 2

Buttrey identified "at least thirteen" different obverse scenes in the first group (Buttrey 1973, p. 52), and found that these scenes are not consistently paired with a reverse numeral. Buttrey found, in fact, that the same reverse die had been used with a number of different obverse scenes, allowing him to suggest the pieces were struck as a "coherent group" in "virtual simultaneous manufacture" (ibid., p. 52).

The token found in the Thames at Putney (Figure 6) bears the same obverse and reverse as one of the spintria in the British Museum collection (Figure 4). We will return to these two particular tokens to consider the perceived differences (see p. 98, below) despite their obvious similarities: both are examples of Buttrey's "Type 5", which is to say, both are examples of the scene numbered " 5 " in the plates accompanying Buttrey's article (i.e. ibid., Plate 3, item 5).

\footnotetext{
${ }^{2} \mathrm{~A}$ scope note on the British Museum website explains the usage of the term "copper alloy":

Copper Alloy (Scope note)

The term 'copper alloy' should be searched for full retrievals on objects made of bronze or brass. This is because bronze and brass have at times been used interchangeably in the old documentation, and copper alloy is the Broad Term of both. In addition, the public may refer to certain collections by their popular name, such as 'The Benin Bronzes' most of which are actually made of brass. The term 'copper alloy' is used in preference to 'billon' (in both Description and Materials) in records for Roman coins. http://www.britishmuseum.org/research/search_the_collection_database/ term_details.aspx?scopeType=Terms\&scopeId=18864.
} 

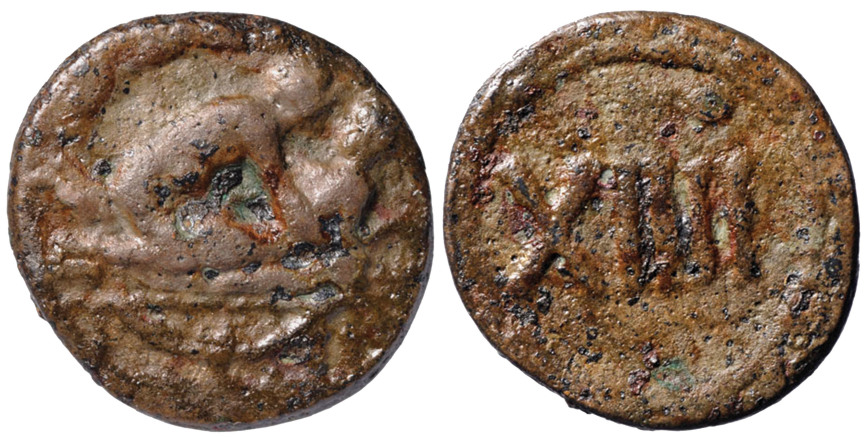

Figure 6: Spintria. Buttrey "Type 5". LON-E98F21. C1st AD. Copper alloy. Museum of London. Image source: http://collections.museumoflondon.org.uk/online/object/794653.html

Buttrey recorded six examples of tokens showing "scene 5", three of which are in the British Museum collection. Each of the six has a different reverse (I, X, XI, XIIII, XV, and AVG). The example shown in Figure 4 has the number "XIIII" on the reverse, i.e. the same form of fourteen as used on the token in the Museum of London. The other two BM examples have the numbers "XI" and "XV". (While Buttrey notes only one example of a Type 5 token with an AVG reverse, Bono Simonetta and Renzo Riva also record a single specimen with an AVG reverse in their study (Simonetta and Riva 1981, p. 11). The only other known example of a spintria with an AVG reverse can be seen in Figure 7).

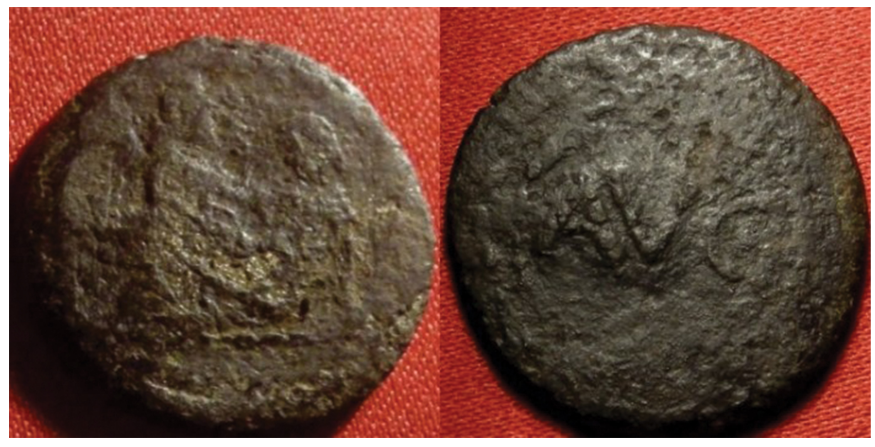

Figure 7: Spintria. Buttrey "Type 1". AVG reverse. C1st AD. Source: Incitatus Coins and Antiquities. Source:

https://www.vcoins.com/en/stores/incitatus_coins/79/product/roman_
spintria_erotic_tessera_time_of_tiberius_heterosexual_scene_with_
male_on_top_reverse_scene_with_avg_in_wreath_only_known_from_1_
example_unique_lasciva_nomismata/166123/Default.aspx


Most of the thirteen scenes identified by Buttrey are paired with a different number on the reverse. For example, he noted seven different numbers on the reverse of the Scene 7 tokens he examined, and five different numbers on the reverse of the Scene 9 tokens. For Buttrey, this is evidence of the absence of a direct correlation between the obverse scene and the reverse numeral: "That there is no meaningful connection between the erotic scenes of the obverse and the reverse numeral, whatever the tokens' use, is proved in that the same obverse scene occurs with differing numbers, and vice versa" (Buttrey 1973, p. 54).

To add to the conundrum, Buttrey identified yet another series of tokens, the obverse of which bear imperial portraits, genre scenes or mythological scenes - he lists a total of twenty-six obverse images - all paired with a reverse Roman numeral in a circle and a wreath (see Figure 8) or the legend "AVG". Moreover, he finds "extensive die-linkage...throughout the group" (ibid., p. 54), allowing him to assert these ostensibly different tokens actually form "a coherent group which must be attributed to a single shop and to a relatively brief period of time" (ibid., p. 54). Buttrey also finds dielinkage between the spintriae and the portraits/genre tokens, specifically: "the spintriae and the Augustus portrait are linked through the reverse AVG die" (ibid., p. 57). While the subjects of the portraits have been disputed, Buttrey argues they show Augustus, Livia and Tiberius.3
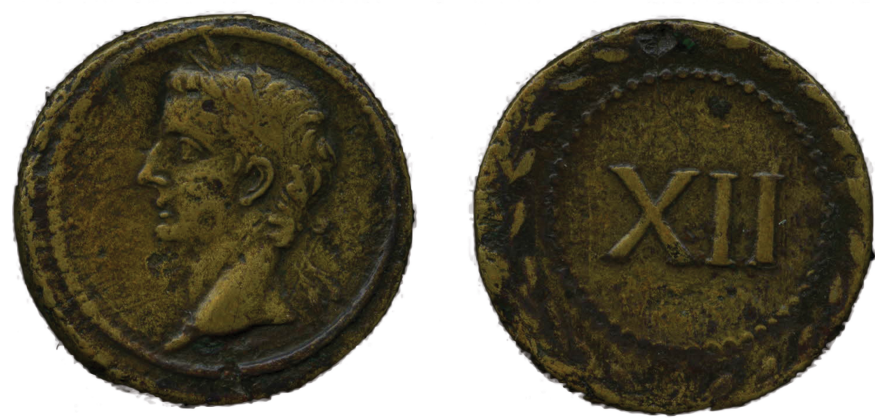

Figure 8: Imperial Portrait: Laureate head of Tiberius. Buttrey "Type 14". BM R.4450. C1st AD. Copper alloy. Diameter: 22mm. Image @Trustees of the British Museum.

\footnotetext{
${ }^{3}$ Augustus, then known as Octavian, succeeded Julius Caesar and was Emperor from 44 BC-14 AD. Augustus divorced his first wife to marry Livia. Augustus and Livia had no surviving children, but Livia's son from her first marriage, Tiberius, succeeded Augustus after various failed manoeuvres to establish an imperial heir. See: Gascoigne, B. (2001) "The Family Life of the Caesars" History World. Available online: http://bit. 1y/22FFlBF. See also Appendix B.
} 
Buttrey uses iconographic evidence from the imperial portrait tokens to identify Augustus and also to establish an approximate date of production. Buttrey's proposed date of manufacture is based on the radiate crown on the head of Augustus, which suggests the radiate tokens had been struck posthumously - i.e. after Augustus's death in 14 AD (see Figure 9). Further consideration of the presence or absence of a fullmen, or lightning bolt, and the inclusion of design details similar to other coins (ibid., p. 55) allows Buttrey to argue for an even more precise date, leading him to conclude the imperial portrait tokens were produced between 22-37 AD.
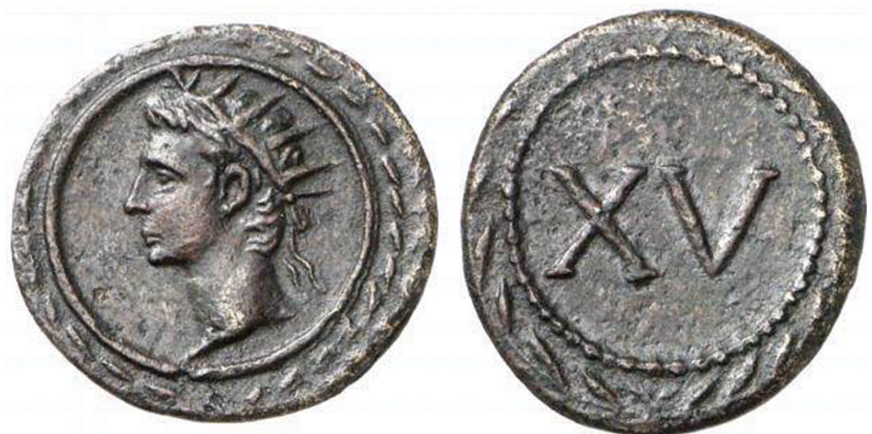

Figure 9: Type 9 "AE Tessera, Augustus. Radiate head of Augustus left within circle and wreath / XV within border and wreath". Source: http://www.wildwinds.com/coins/ric/augustus/i.html

As to usage, Buttrey offers a number of suggestions drawn from the body of literature that has discussed these items. For example, they may have been used to tally asses (an "as" is a Roman coin; during the first century $\mathrm{AD}$, sixteen asses were equal to one denarius). Another suggestion is that they may have been admission tokens, such as theatre tickets; Friedländer (1886) proposed they were used as tickets "auf die man in Bordelle Einlass erhielt" ("to obtain entry to brothels"), all of which Buttrey rejects: "there is no evidence for any of this" (ibid., p. 53). Buttrey suggests instead "the tokens may have served as counters in gaming, the numbers corresponding to moves or positions or to points wagered or gained" (ibid., p. 54).

That they might be gaming pieces is a suggestion that has been repeated by several authors. Alberto Campana (2009) offers an overview of the literature on the spintriae, identifying French numismatist Robert Mowat (1898) as the first to suggest the spintriae may have been gaming pieces and that they should be studied like any other ancient coin. Later writers, including Buttrey (1973), Bateson (1999), Fishburn (2007) and Campana (2009 and 2013) have echoed Mowat's suggestion that the tokens had a ludic function. 
In a footnote, Campana (2009) attributes to Benassi, Giodani and Poggi (2003) the idea that the erotic and non-erotic imagery may have been used to distinguish each players' set of pieces in a game like duodecim scripta [my emphasis]: $:$ |

Questi autori ipotizzano anche che l'impiego dell'oricalco (o del rame rivestito con oro) serviva per dare maggiore preziosità ai gettoni e che l'evidente contrasto tra tessere erotiche e quelle non erotiche potrebbe essere voluto per distinguere le pedine di ognuno dei giocatori in assenza di una diversa colorazione. [These authors also speculate that the use dell'oricalco (or copper coated with gold) was used to give more precious tokens and that the apparent contrast between tiles erotic and non-erotic might be wanted to distinguish the pieces of each of the players in the absence of a different colouring] (Campana 2009, p. 56 n. 50)

Campana identifies Nadrowski (1906) as the source of the idea that the spintriae were specifically brothel tokens, 5 while Gnecchi (1907) equated the reverse numeral with a price or value in asses of the service depicted (ibid., p. 46). "Da allora", Campana continues, "l'ipotesi che le spintriae dovessero servire a pagare le 'prestazioni' nei lupanari divenne la prevalente e ancora oggi la più accreditata" ["Since then, the hypothesis that the spintriae were to be used to pay for the 'performance' in brothels became prevalent and even today is the most accepted"] (ibid., p. 46).

The brothel token hypothesis seems to be predicated upon an assertion advanced by Suetonius that "people could...be executed for carrying a ring or coin, bearing Augustus's head, into a privy or a brothel" (Suetonius, Tiberus 58). Buttrey suggests that Suetonius's comments, written about 100 years after the death of Augustus, alluding to Tiberius's allegedly scandalous activities with groups of young men and women (Suetonius, Tiberus 43-44) probably derive from the very existence of the tokens rather than provide a reliable explanation of them (Buttrey 1973, p. 57-58).

Economist Geoffrey Fishburn considers how a brothel token sub-economy would work; specifically, what systems would have to exist to facilitate not

\footnotetext{
${ }^{4}$ In a Coins at Warwick blog post, the idea that the erotic and non-erotic tokens were used to distinguish each players' pieces is erroneously attributed to Buttrey. See Rowan (2015).

${ }^{5}$ However, Friedländer's 1886 commentary on Martial, as cited by Buttrey, predates Nadrowski by twenty years. See Buttrey 1973, p. 53; cf. Campana 2009, p. 46.
} 
only the initial purchase of the tokens by brothel patrons, but also for the prostitutes, pimps or brothel keepers to redeem the used tokens for their monetary value before concluding there is little evidence to support the brothel token hypothesis (Fishburn 2007, pp. 228-235). Fishburn also notes that no later commentator lends any support to Simonetta and Riva (1981, 1984), the leading proponents of the "brothel token" hypothesis. It's also worth noting that there would seem to be an inherent contradiction in producing objects bearing an image of Augustus specifically for use as brothel tokens when such usage is apparently forbidden.

Simonetta and Riva suggest the spintriae were produced in two phases in a later period, between 70-95 AD (Simonetta and Riva 1981, p. 10). While the ancient literary evidence relating to the spintriae is scant - apart from the reference in Suetonius, the only other mention appears to be a line from Martial's Epigrams (8.78.9) about showering "lasciva nomismata" (lascivious coins) on to a crowd. This line is used by Simonetta and Riva to associate the tokens with Domitian (81-96 AD), whom the epigram celebrates. However, it is not clear that Martial's "lasciva nomismata" refers to the spintriae or that "lasciva" can or should be interpreted as "lascivious" in the contemporary, pejorative, sense. Moreover, a tomb in Modena has yielded a spintria along with four coins: one depicting Augustus (RIC 207); one depicting Livia (RPC 1154); a coin minted under Caligula also depicting Augustus (RIC 56) and a coin depicting Claudius (RIC 113).6 The burial is dated to "no later than the beginning of Nero's reign" (54-68 AD), thereby pre-dating Domitian's reign (81-96 AD) and Simonetta and Riva's earliest estimated period of production (See Campana 2009, pp. 48-50).

Simonetta and Riva seek to establish the date of production of the spintriae by comparing the iconography of their Scene 4 (Buttrey's Type 9) with a Pompeiian fresco in the so-called "Secret Cabinet" of the National Archaeological Museum of Naples (Figure 10; Figure 11). They reason that the fresco must date to the period between the two earthquakes that damaged Pompeii, the first in $62 \mathrm{AD}$ and the second, in $79 \mathrm{AD}$, which destroyed the city completely (Simonetta and Riva 1981, p. 28).

\footnotetext{
${ }^{6}$ The numismatic abbreviations RIC and RPC refer respectively to Roman Imperial Coinage and Roman Provincial Coinage; the numbers refer to particular coins. See, for example: http://numismatics.org/ocre/id/ric.1(2) .aug. 207.
} 


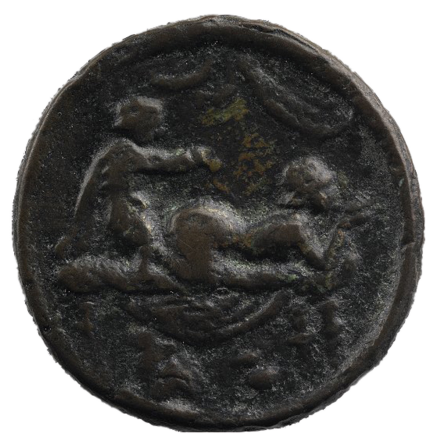

Figure 10: Spintria. Simonetta \& Riva Scene 4/Buttrey "Type 9". BM R.4485. C1st AD. Copper alloy. Diameter: $19 \mathrm{~mm}$. Image $\bigcirc$ Trustees of the British Museum

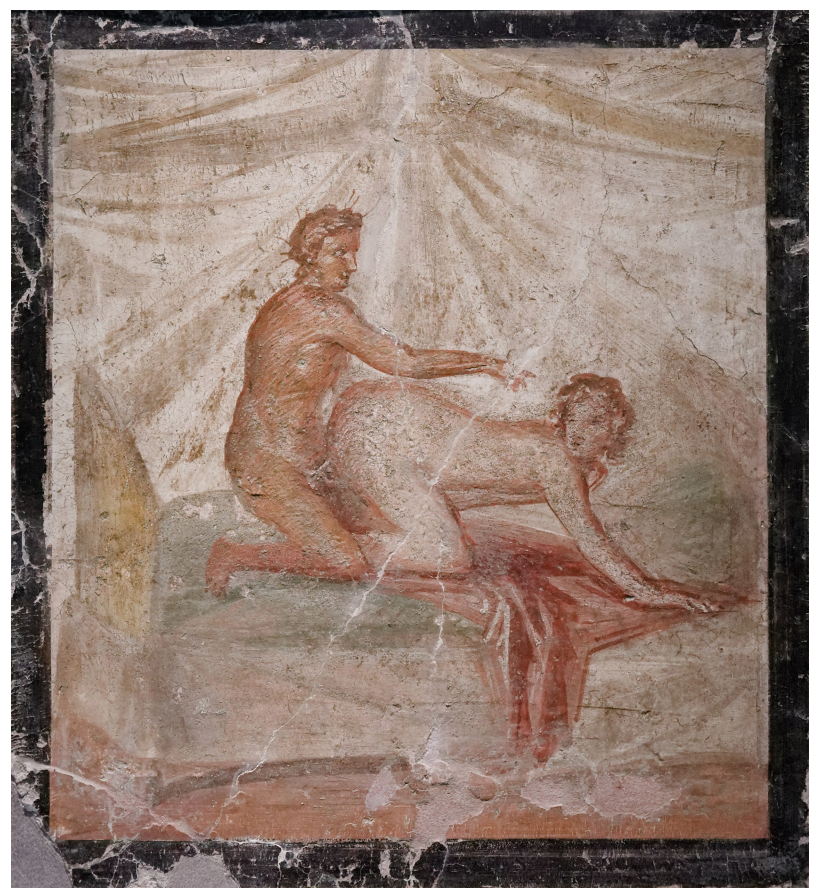

Figure 11: Fresco. Pompeii. C1st AD. W. $42 \mathrm{~cm} \times$ H. $46 \mathrm{~cm}$. Secret Cabinet Collection. National Archaeological Museum of Naples. Inv. 27696. Image: Marie-Lan Nguyen, Wikimedia Commons.

Simonetta and Riva refer also to similar iconography on two Roman oil lamps in the British Museum, both dated to ca. 40-80 AD (Figure 12; Figure 13). Other authors have also commented on the correspondence between the iconography of the spintriae and other representational forms (see, for 
example, Clarke 1998, Ch. 8; Talvacchia 1999, Ch. 3). Luciana Jacobelli suggests the similarity could mean no more than that the erotic iconography apparent in the spintriae, oil lamps, frescoes and other representational forms is derived from a common source, perhaps a lost catalogue of sexual positions such as the work attributed to Elephantis (referred to by Suetonius, Tiberius 43; and Martial, Epigrams, XII, 43).

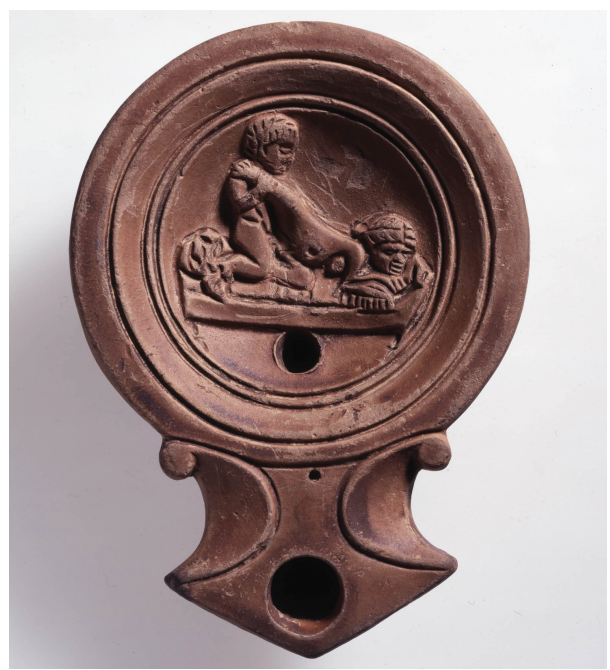

Figure 12: Lamp with erotic motif. BM Q.887. Italy. Pottery. 40-80 AD. Length: $11.8 \mathrm{~cm}$. Width: $8.3 \mathrm{~cm}$. Image $\bigcirc$ Trustees of the British Museum.

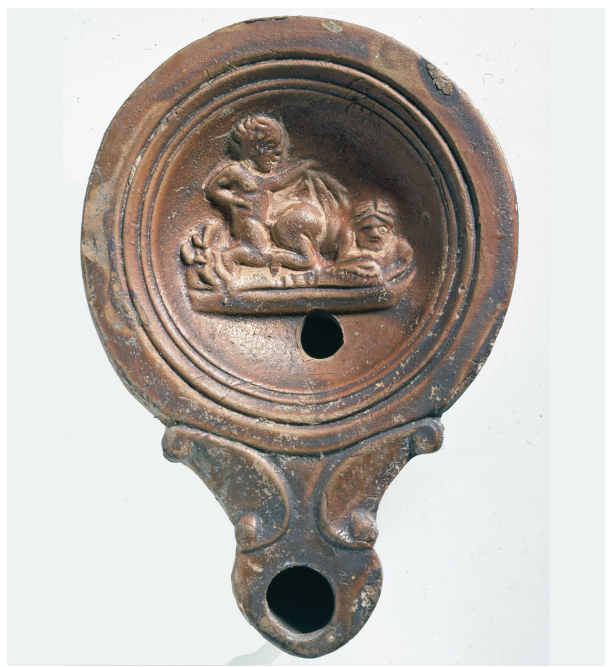

Figure 13: Lamp with erotic motif. BM Q.888. Italy. Pottery. 40-80 AD. Length: $11.8 \mathrm{~cm}$. Width: $8.2 \mathrm{~cm}$. Image () Trustees of the British Museum. 
Jacobelli has undertaken an extensive study of the frescoes in the Suburban Baths in Pompeii. She notes that, at one point in its history, the wall paintings in the changing room area (the apodyterium) consisted of a series of erotic scenes, each of which was numbered (see Figure 14). Jacobelli discusses the frescoes in relation to the spintriae as these tokens constitute the only other known example of enumerated erotic art (Jacobelli 1995, pp. $70 \mathrm{ff})$.

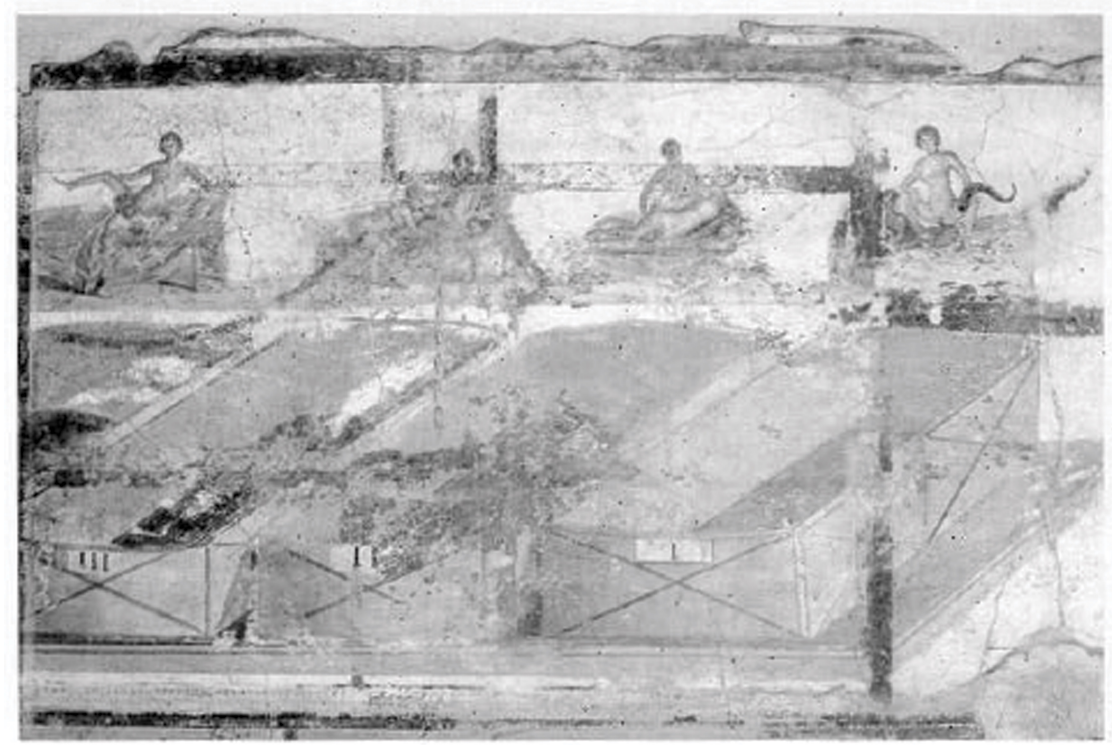

Figure 14: The south wall of the apodyterium; the left side of the upper part of the wall depicts a series of numbered boxes, each adjacent to an erotic scene. Image: Jacobelli (1995) p. 34.

The decorative scheme in the apodyterium was designed in such a way that eight erotic images, each adjacent to a painted box on a painted shelf, appeared on the upper section of the south wall while a further eight images, also aligned with boxes on a shelf, were apparently in the upper section of the adjacent east wall. Due to damage to the east wall, the upper part of the fresco is missing. However, the numbered boxes remain visible and the I-VIII sequence on the south wall continues IX-XVI on the east wall. Jacobelli reasons that the erotic images would also have continued on the east wall, along with the numerical sequence on the boxes.

\footnotetext{
${ }^{7}$ Jacobelli notes that the apodyterium was partially re-painted some time before the
} 
Jacobelli discusses evidence (holes in the floor and wall) that indicates real shelving may have been installed adjacent to the painted shelves, and that clothing may have been stored on the shelves in real baskets adjacent to the painted baskets (ibid., pp. 61-64). She goes on to suggest that the erotic imagery, possibly derived from a lost sex manual, perhaps a work of Greek erotica, may have functioned on the one hand to represent a sense of good health and well-being, appropriate to the environment of the changing room, but the scenes may also have functioned as amusing aides memoires to help visitors to the baths recall the adjacent basket in which they have left their clothes and sandals (ibid., p. 69).

Jacobelli goes on to note that while the scenes depicted on the spintriae appear to be exclusively heterosexual pairings, two of the apodyterium scenes show multiple couplings. One shows an engagement involving two males and one female, while the other shows two male and two female participants. The former shows the central male figure engaged in simultaneous homosexual and heterosexual couplings while the latter depicts a heterosexual scenario at the centre, with each of the two central participants also engaged with a second partner of the same sex. Such complex symplegmata 8 are unknown in the spintriae.

While Jacobelli comments on the exclusively heterosexual nature of the couplings depicted in the spintriae she refers in a footnote to "an hypothesis" (p. 70) that Buttrey's Type 5 may depict two men (see Figure 4 above). Similarly, Bette Talvacchia notes "the tesserae known to me appear to show only heterosexual couples, although some have surfaces that are worn or damaged enough to make the reading less than certain" (Talvacchia 1999, p. 65). Buttrey, however, makes no reference to any "hypothesis" regarding the sexual orientation of the couplings depicted in the spintriae, although his terminology ("an erotic scene of a couple engaged in one position or another of copulation of fellation" (Buttrey 1973, p. 52)) implies a representation of heterosexual activity. Jacobelli doesn't elaborate on the "assumption" but the "hypothesis" to which she alludes may be derived from some of the British Museum's online descriptions as the British Museum website identifies five of the spintriae in its collection as depictions of homosexual

eruption of Vesuvius in 79 AD. The over-painting specifically effaced the erotic frescoes as it was restricted to the middle and upper sections of the east wall and the south wall. Two windows were also filled-in and the passageway to the fridgiarium closed off. See Jacobelli 1995, p. 28.

${ }^{8}$ Symplegma (plural: symplegmata) from the Greek "entanglement", is an art historical term used to describe entwined bodies usually, but not exclusively, involved in some form of sexual activity. 
couplings.

As previously noted, the British Museum has "around 25" spintriae in its collection, including both erotic and non-erotic (i.e. imperial portraits/genre scene) types. Of these 25, only eleven can be found via the website (British Museum $>$ Research $>$ Collection Online). 9 Two of the eleven are imperial portraits. The remaining nine erotic tokens consist of three Type 7 scenes (R.4481; R.4482; R.4483); two Type 5 scenes (R.4473; R.4476) and one each of Type 1 (R.4467); Type 3 (R.4470); Type 6 (R.4478); and Type 9 (R.4485). The British Museum's online description for both the Type 7 and the Type 5 tokens interprets the obverse image as depicting a homosexual scene:

[Type 7] Male lovers on bed. The passive partner is looking back at the active lover and reaches back to hold his upper arm. (R.4481; R.4482). Source: British Museum.10

[Type 7] Male lovers on bed. The eromenos (younger 'beloved', passive) is looking back at the erastes (older, active lover) and reaches back to hold his partner's upper arm. (R4483). Source: British Museum.11

[Type 5] Male lovers on bed. The erastes (older, active lover) wears a wreath while the eromenos (younger 'beloved', passive) is bareheaded and is looking back at his partner. (R.4473; R.4476). Source: British Museum.12

However, there is no clear visual evidence in the scenes themselves to support this interpretation.

\footnotetext{
${ }^{9}$ The search term "spintria" returns eleven items, erotic and non-erotic tokens. The plural, "spintriae", also returns eleven results. These include the two imperial portraits, two Type 5 token and the three Type 7 tokens, along with three C18th pen-and-ink drawings, each showing six spintriae from the Townley collection (a fourth pen-and-ink drawing is not illustrated).

${ }^{10}$ Online object description (R.4481): http://www.britishmuseum.org/research/ collection_online/collection_object_details . aspx?objectId=3622219\&partId=1\& searchText=spintria\&page $=1$.

${ }^{11}$ Online object description (R4483): http://www.britishmuseum.org/research/ collection_online/collection_object_details . aspx?subject=16808\&ILINK\% 7C34484, \%7CassetId=951032\&objectId=3028084\&partId=1.

${ }^{12}$ Online object description (4476): http://www.britishmuseum.org/research/ collection_online/collection_object_details.aspx?objectId=3405469\&partId=1\& searchText=foreshore\&page $=1$.
} 
The textual description on the British Museum website describes the Type 5 token referred to above (p. 89) as depicting "male lovers on bed" (see Figure 4). Meanwhile, the Portable Antiquities Scheme online record for an identical token in the Museum of London collection refers to "naked lover lovers in a sexual act" (see Figure 6). In this instance, however, the participants are seen as heterosexual: "the female lies on her front beneath the male who straddles her" (Creed, 2011). Bette Talvacchia refers to "the woman in scene 7 of the spintriae" (Talvacchia 1999, p. 64).

The "hypothestis" Jacobelli refers to with regard to the Type 5 token and the descriptions on the British Museum website may be influenced by the etymological derivation of the term spintria. The term, from the Greek "sphinkter", was applied originally to male prostitutes and, later, to the participants in Tiberius's erotic activities on Capri (Suetonius Tiberius 43). As Jacobelli notes, it is only since Spanheim (1664) that the term has been used to refer to these numismatic curiosities rather than to individuals or their proclivities (Jacobelli 1995, n. 160).

Another suggestion sometimes offered by way of explanation of the spintriae is that they may have been game pieces. However, Simonetta and Riva 1981, p. 22 eschew the possibility the spintriae are game pieces, asserting that, having argued they are brothel tokens, it should not be necessary make the case that they are not game pieces. Nonetheless, Simonetta and Riva declare that the Roman enthusiasm for games is well-documented by the Latin authors, who have written about games in detail, but have not described a game that uses these bronze tokens, 13 moreover, they continue, there is no obvious game in which these tokens could be used and they specifically rule out latrunculi and duodecim scripta.

However, Simonetta and Riva's argument as to why the spintriae are not game pieces is not entirely convincing: absence of evidence is not evidence of absence. As for the suggestion that the Latin authors have not described a game played with bronze tokens, we know that only a fragment of classical texts have been recovered; Robert Fowler, for example, estimates $10 \%$ of classical texts have survived (Banerji 2013, online). It may well be that a fragment of text, or a cache akin to Herculaneum's so-called Villa of Papyri will come to light at some point in the future, with an account of either a game or some other definitive example of the usage of these peculiar jetons.

While the literary evidence is lacking, there is also an absence of archae-

\footnotetext{
${ }^{13}$ There is a scene in Petronius's Satyricon (XXXIII) in which the ostentatious Trimalchio plays a game of latrunculi with gold and silver coins. The intention is to emphasise the vulgar excess of the character.
}

Board Game Studies Journal 11, pp. 101-121 DOI $10.1515 /$ bgs-2017-0005 
ological accumulation as, thus far, no examples of multiple spintriae have been recovered in a context that contains dice and game board fragments. Until such a discovery is made, conclusive evidence that the spintriae are pieces from a board game will remain wanting and Fishburn's suggestion that the spintriae might have been used as form of "locker token" for patrons of the baths (Fishburn 2007, p. 233) seems to be the most plausible explanation to be derived from the archaeological context and current finds of isolated and individual spintriae.

\section{Appendix A}

The second example of the second series Buttrey identifies in the BM collection (AE19 4.23) has a reverse numeral prefixed by what looks like lambda rather than an "A". The obverse, showing the female participant Venus pendula, is rather more worn than the example shown here in Figure A1.

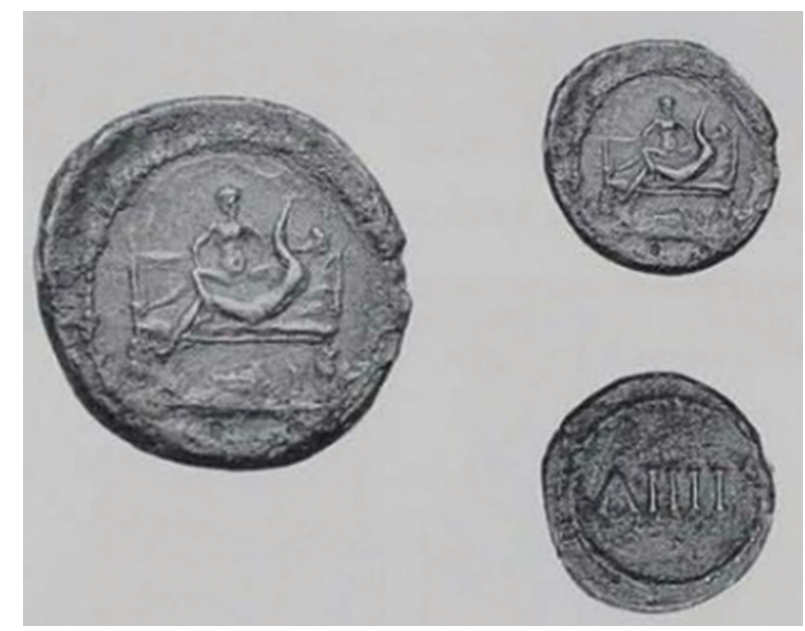

Figure A1: Spintria. Type 10 series 2. Source: Classical Numismatic Group in association with Numismatica Ars Classica. Auction 40. December 4 1996. Lot 1352. p. 160 [online] Source: https://issuu.com/cngcoins/docs/cng_40

A third tesserae in the BM collection (AE23 9.08) with an obverse scene of two figures treading grapes and a reverse numeral (XVI) prefixed with an "A", apparently overlooked by Buttrey, is included in Tray 23. The same obverse/reverse pairing can be seen in Figure A2. 

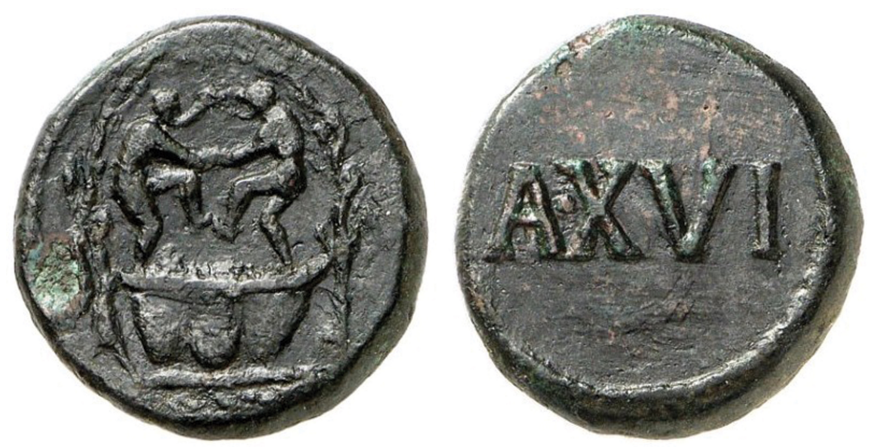

Figure A2: Spintria. Obverse: Two figures treading grapes; Reverse: A XVI P-F Jacquier, Numismatique Antique, Auction 40 (16 Oct 2015) Lot 199. Source:

https:

$/ /$ www . sixbid. com/browse . html ?auction=2249\&category=45214\&lot=1902328

\section{Appendix B}

\begin{tabular}{|c|l|}
\hline \multicolumn{3}{|c|}{ Chronology of Roman Emperors } \\
\hline 46 BC-44 BC & Dictator Julius Cesar (born 100 BC) \\
\hline 27 BC-14 AD & Empero Augustus (born 63 BC) \\
\hline 14 AD-37 AD & Emperor Tiberius (born 42 BC) \\
\hline 37 AD-41 AD & Emperor Caligula (born 12 AD) \\
\hline 41 AD-54 AD & Emperor Claudius (born 10 BC) \\
\hline 54 AD-68 AD & Emperor Nero (born 37 AD) \\
\hline 68 AD-69 AD & Emperor Galba (born 3 BC) \\
\hline 69 AD & Emperor Otho (born 32 AD) \\
\hline 69 AD & Emperor Vitellius (born 15 AD) \\
\hline 69 AD-79 AD & Emperor Vespasian (born 9 AD) \\
\hline 79 AD-81 AD & Emperor Titus (born 39 AD) \\
\hline $81 \mathrm{AD}-96 \mathrm{AD}$ & Emperor Domitian (born 51 AD) \\
\hline
\end{tabular}

\section{References}

Banerji, R. (2013). "Unlocking the Scrolls of Heculaneum". In: BBC News Magazine. [Online; posted 20 December 2013]. URL: http://www. bbc. co.uk/news/magazine-25106956. 
Barford, P. (2012). "Brothel Token from London?" In: Portable Antiquity Collecting and Heritage Issues. [Blog Post] Jan 6 [available online]. URL: http://paul-barford.blogspot .co.uk/2012/01/brothel-tokenfrom-london.html.

Beard, M. (n.d.). "A Don's life: A Roman brothel token?" In: Times Literary Supplement. [Blog Post] Jan 5 [available online]. URL: http: // timesonline.typepad.com/dons_life/2012/01/a-roman-brotheltoken.html.

Buttrey, T. (1973). "The "Spintriae" as a Historical Source". In: The Numismatic Chronicle 13, pp. 52-63. URL: http://www.jstor.org/stable/ 42664663.

Campana, A. (2009). "Le spintriae: tessere Romane con raffigurazione erotiche". In: La donna romana: immagini e vita quotidiana : atti del convegno : Atina, 7 marzo 2009. Historia (Centro di studi storici Saturnia). Diana, pp. 43-96. URL: https://books.google.pt/books?id=7CcoAQAAIAAJ.

- (2013). "Les spintriae et leur possible function ludique". In: Archéothéma 31, p. 66.

Champlin, E. (2011). "Sex on Capri". In: Transactions of the American Philological Association 141.2, pp. 315-332. URL: http://www . jstor. org/stable/41289747.

Clarke, J. (1998). Looking at Lovemaking: Constructions of Sexuality in Roman Art, 100 B.C. - A.D. 250. pt. 250. University of California Press. URL: https://books .google.pt/books?id=bwNdgd8cQcgC.

Classical Numismatic Group in association with Numismatica Ars Classica. Auction 40 (Dec. 4, 1996). URL: https://issuu.com/cngcoins/docs/ cng_40.

Creed, K. (2011). "ON-E98F21: A Roman Token". In: Portable Antiquities Scheme. URL: https://finds.org.uk/database/artefacts/record/ id/455487.

- (2012). "Roman spintria from the banks of the Thames". In: Portable Antiquities Scheme. [Blog post] 6 January. URL: https://finds.org. uk/news/story/227.

Fehauler, M. (2016). In: URL: https://www . uni-muenster.de/imperia/ $\mathrm{md} /$ content/archaeologie/tesserae_i-xi_mai_2016_.pdf.

Fishburn, G. (2007). "Is that A Spintria In your Pocket or Are You Just Pleased to See Me?" In: Regarding the Past: Proceedings of the 20th Conference of the History of Economic Thought Society of Australia. Ed. by P. Earl and B. Littleboy. University of Queensland, pp. 225-236. Gascoigne, B. (n.d.). "The Family Life of the Caesars". In: History World. URL: http://bit.ly/22FFlBF. 
Jacobelli, L. (1995). Le pitture erotiche delle Terme Suburban di Pompeii. Rome: L'Erma di Bretschneider.

Jones, J. (Jan. 4, 2012). "Porn yesterday: Roman brothel tokens and the rise of erotic art". In: The Guardian. URL: http://www.theguardian. com/artanddesign/jonathanjonesblog/2012/jan/04/porn-romanbrothel-tokens-erotic-art.

Museum of London (2012). Roman brothel token discovered on Thames foreshore. Press release, Jan. 5. URL: http://bit.1y/2x9juvq.

Pavlos S. Pavlou (n.d.). URL: https : / / www . vcoins . com/en/stores / pavlos_s_pavlou_numismatist/131/product/roman16th_to_17th_ cent_ad_copy_of_aespintriaeerotic_sceneretrograde __roman_ numerals_vii/222124/Default.aspx.

"Roman brothel token discovered in Thames" (Jan. 4, 2012). In: The Daily Telegraph. URL: http://www.telegraph.co.uk/news/earth/8991212/ Roman-brothel-token-discovered-in-Thames.html.

Rowan, C. (2015). "Ain't talkin' 'bout love. Roman "Spintriae" in context". In: Coins at Warwick. August 1. [Blog post]. URL: http: / / blogs . warwick.ac.uk/numismatics/entry/aint_talkin_bout.

Simonetta, B. and R. Riva (1981). Le Tessere erotiche romane (spintriae): quando ed a che scopo sono state coniate. Gaggini-Bizzozero. URL: https: //books . google.pt/books?id=u9VcMQAACAAJ.

- (1984). "Nuovo contributo alla nostre conoscenze sulla 'spintriae'". In: Schweizer Münzblätter 136, pp. 88-92.

Suetonius (1958). The Twelve Caesars. Translated by Robert Graves.

Talvacchia, B. (1999). Taking Positions: On the Erotic in Renaissance Culture. Princeton University Press. URL: https : / / books . google .pt/ books?id=s3\%5C_-Qd8KvbsC.

Venning, A. (Jan. 6, 2012). "After an explicit coin used to pay for pleasure is found in the Thames, the X-rated story of the Roman sex slaves of Britain". In: Daily Mail. URL: http: //www.dailymail.co.uk/news/ article-2083295/Explicit-coin-Thames-X-rated-story-Romansex-slaves-Britain.html.

Department of Science and Technology

University of Suffolk, Ipswich, Suffolk IP4 1QJ UK

e.duggan@uos.ac.uk 